\title{
Sanitary aspects of the herd and milk quality in family farming properties in the Western Amazon
}

\section{Aspectos sanitários do rebanho e da qualidade do leite em propriedades de agricultura familiar na Amazônia Ocidental}

\author{
Marcos Aurelio Lopes ${ }^{1 *}$; Eduardo Mitke Brandão Reis ${ }^{2}$; Fabiana Alves Demeu ${ }^{3}$; \\ Fabio Raphael Pascotti Bruhn'; Andre Luis Ribeiro Lima ${ }^{5}$; Gideon Carvalho \\ Benedicto ${ }^{5}$; Geraldo Marcio da Costa ${ }^{1}$; Felipe Berbari Neto ${ }^{6}$
}

\begin{abstract}
The aim of this study was to analyze 100 dairy farms under family farming regime from the mesoregion of the Acre Valley in the Western Amazon, regarding the sanitary and milk quality aspects, considering different levels of milk yield. The data were collected from March to June 2016, from a semi-structured form, containing 301 questions, through on-site observation, as well as the answers obtained with the owners; and recorded in SPSS ${ }^{\circledR}$ spreadsheets. The descriptive statistics was adopted and, with the aid of the cluster analysis methodology, the cowmen were divided into two clusters with different characteristics in terms of productivity (higher and lower). Some relevant differences among the properties were identified: those belonging to the higher productivity cluster had higher family income and showed greater use of technologies, such as expansion tank and milking machine. In addition, they showed higher vaccination rates against clostridial diseases and rabies. Regarding milk quality, there was higher pre-dipping indices. Milk analyses (somatic cell count, total bacteria count, temperature, protein, fat, bacterial inhibitors, reductase and milk solids-not-fat) were performed on any property. It was concluded that actions are needed to improve productivity and aspects related to milk quality.
\end{abstract}

Key words: Acre. Amazon. Rural development. Diagnosis. Dairy farming.

\section{Resumo}

Objetivou-se analisar 100 propriedades leiteiras, em regime de economia familiar, da Mesorregião do Vale do Acre, na Amazônia Ocidental, no que diz respeito aos aspectos sanitários e da qualidade do leite, considerando diferentes níveis de produtividade de leite. Os dados foram coletados no período de março a junho de 2016, a partir de um formulário semiestruturado, contendo 301 questões, por meio da observação in loco, bem como pelas respostas obtidas com os proprietários; e cadastrados em planilhas

${ }^{1}$ Prof. Dr. Titular, Universidade Federal de Lavras, UFLA, Departamento de Medicina Veterinária, Lavras, MG, Brasil. E-mail: malopes@dmv.ufla.br; marciocostavet@gmail.com

2 Prof. Dr., Universidade Federal do Acre, UFAC, Centro de Ciências Biológicas e da Natureza, Rio Branco, AC, Brasil. E-mail: edumitke@hotmail.com

3 Prof ${ }^{a}$ M.e, Instituto Federal de Rondônia, IFRO, Ariquemes, RO. Discente do Curso de Doutorado, Programa de Pós-Graduação em Ciências Veterinárias, UFLA, Lavras, MG, Brasil. E-mail: fabiana.alves@ifro.edu.br

4 Prof. Dr., Universidade Federal de Pelotas, UFPel, Departamento de Veterinária Preventiva, Capão do Leão, RS, Brasil. E-mail; fabio_rpb@yahoo.com.br

5 Profs. Drs., Universidade Federal de Lavras, Departamento de Administração e Economia, Lavras, MG, Brasil. E-mail: andreluisnep@yahoo.com.br; gideon.benedicto@dae.ufla.br

6 Prof. Dr., Universidade Federal do Espírito Santo, UFES, Departamento de Medicina Veterinária, Alegre, ES, Brasil. E-mail: berbarineto@hotmail.com

Author for correspondence 
do SPSS ${ }^{\circledR}$. Adotou-se a estatística descritiva e, com auxílio da metodologia de análise de clusters, os pecuaristas foram divididos em dois grupos com características distintas em termos de produtividade (maior e menor). Foram identificadas algumas diferenças relevantes entre as propriedades: as pertencentes ao grupo maior produtividade possuíam renda familiar mais elevada e apresentaram maior uso de tecnologias, como tanque de expansão e ordenhadeira mecânica. Além disso, apresentaram índices mais elevados de vacinação para clostridioses e raiva. Quanto à qualidade do leite, observouse maiores índices de realização de pré-dipping. Em nenhuma propriedade eram realizadas análises do leite (contagem de células somáticas, contagem bacteriana total, Temperatura, Proteína, Gordura, inibidores bacterianos, redutase e sólidos não gordurosos) Concluiu-se que são necessárias ações que visem à melhoria da produtividade e de aspectos referentes à qualidade do leite.

Palavras-chave: Acre. Amazônia. Desenvolvimento rural. Diagnóstico. Pecuária leiteira.

\section{Introduction}

Milk production can be considered as one of the pillars of Brazilian agricultural production, being significantly explored in different regions with producers at diverse organizational and technological levels (WILLERS et al., 2014). The importance that the activity has acquired is undeniable, both in economic performance and in the generation of permanent jobs (ZOCCAL et al., 2008).

Although Brazil is one of the world's largest producers of cow's milk, with 34 billion liters in 2015. However, the herd productivity is low, being 1,381 liters per cow/year (SILVA; SILVA, 2016). Moreover, Brazilian milk production has very low zootechnical, economic and productivity indexes, which makes it an unattractive activity (NOVO; SCHIFFLER, 2006).

The activity goes through a phase where the producer needs to become professionalized, besides adapting to the criteria established by current legislation via Normative Instruction No. 62 (BRASIL, 2011). Generally, milk obtained under poor hygienic and sanitary conditions is a risk to public health, especially when consumed without heat treatment (REIS et al., 2017). It is clear that milk produced nationally does not always show desired quality, but has generated discussion and development of new policies in order to encourage milk production, such as the National Milk Quality Improvement Program (NERO et al., 2005). It it is noteworthy that, in order to keep healthy in cattle herds, it is necessary to implement effective sanitary programs (PEREIRA et al., 2014).
In the State of Acre, dairy farming is characterized by the predominance of low technological level, mainly related to milk quality, herd health and milking infrastructure, storage and milk conservation in the property (ANDRADE et al., 2014), requiring several technical and managerial efforts that, according to Lopes et al. (2015a), can increase productivity, profitability and improve the quality of produced milk.

However, little is known about the profile of these properties, being necessary studies to know their characteristics and later to conduct programs that seek to interfere in the production weaknesses. The characterization of milk production systems in the mesoregion of the Acre Valley becomes important for the identification of limitations and perspectives of the productive sector, as well as the implementation of regional development projects; besides targeting public policies for dairy farming of the State.

In this sense, faced with the inexistence of research related to the theme in the region, the objective was to analyze 100 dairy farms under the family farming regime from the mesoregion of the Acre Valley, regarding the health and milk quality of herds, considering different levels of milk productivity.

\section{Material and Methods}

The research was performed in 100 farms under family farming regime located in the mesoregion of the Acre Valley, in the Western Amazon, from March to June 2017. The studied geographical area 
is composed of 14 municipalities: Acrelândia (6 producers), Assis Brasil (3), Brasiléia (7), Bujari (4), Capixaba (8), Epitaciolândia (7), Manoel Urbano (4), Plácido de Castro (11), Porto Acre (6), Rio Branco (16), Santa Rosa dos Purus (5), Sena Madureira (12), Senador Guiomard (9), and Xapuri (2). The producers were selected at random (GUDKOVA et al., 2016) from the list provided by the State Secretariat of Agriculture (SEAP) Secretariat of Agroforestry extension and family farming of the state of Acre (SEAPROF), regardless of the marketed milk volume or the adopted production system. The definition of the number of interviewees was estimated according to Barbetta (2003), considering a maximum sampling error of $5 \%$.

For the interviews and diagnosis, a semistructured form containing 301 questions was used, adapted by Lopes et al. (2016). These questions were divided into themes: producer and property registry (52 questions), herd characterization (12 questions), and milk production (237 questions). This last topic includes the production system, milk quality, milking management, milk analysis, and sanitary control.

In the Excel ${ }^{\circledR}$ software, the descriptive statistics was used, calculating the average, standard deviation, median, interquartile range, minimum and maximum (LOPES et al., 2015b). Using the software SPSS 20.0 (IBM, 2011), the element of the questionnaire was analyzed: productivity, obtaining a cohesive result, liable for analysis and, from these items, the milk producers were divided into clusters called "higher productivity" (1,755.65 liters/hectare/year) and "lower productivity" (492.75 liters/hectare/ year) using the K-means non-hierarchical method (CORRAR et al., 2009; HAIR et al., 2009). The multivariate cluster analysis allows that clusters with characteristics similar to each other and distinct from the other clusters being obtained by choosing one or more variables (KAUFMAN; ROUSSEAU, 1990).

The normality test of Shapiro-Wilk was performed to evaluate the distribution of continuous variables, being detected that there was not normal distribution and/or homoscedasticity. These variables were expressed through the median and interquartile range, and the Mann-Whitney U test was performed for multiple comparison between the higher and lower productivity clusters (MAROCO, 2010). The difference was statistically significant when $\mathrm{p}<0.05$.

\section{Results and Discussion}

The characterization of the milk producing properties allowed knowing the aspects related to the adopted herd health and milk quality in the mesoregion of the Acre Valley reproductive aspects, which can help the producers to identify the most critical points within the production system. Regarding the correlation analyses applied among the variables of quantitative nature, significant correlations were observed among the cattle men from the higher and lower productivity clusters in the indexes productivity $(\mathrm{L} / \mathrm{ha} /$ year $)(\mathrm{p}=0.000)$ and family income $(\mathrm{R} \$$ month $)(\mathrm{p}=0.000)$.

Regarding the higher productivity cluster, with 22 producers, the average, standard deviation (SD), median, interquartile range (IR), minimum and maximum value of $1,839.60 ; 733.65 ; 1,755.65$; $2,633,21 ; 1,095.00$, and 4,380.00 L/ha/year was obtained, while in the lower productivity cluster, with 78 producers, it was $558.45 ; 299.30 ; 492.75$; 419.97; 91.25; and 1,460.00, respectively. These results are much lower than those found by Lopes et al. (2007) $(3,445.12 \mathrm{~L} / \mathrm{ha} / \mathrm{year})$ and Ferrazza et al. (2015) $(10,816.10 \mathrm{~L} / \mathrm{ha} /$ year $)$; both in properties with family workforce in the State of Minas Gerais, Brazil. Considering these low productivities, according to Lopes et al. (2012), many managerial and even technological efforts are necessary aiming to increase daily averages without increasing the average variable cost. An alternative is, according to the researchers, to increase productive efficiency, i.e., productivity per matrix, thus optimizing the expenses with workforce, medicines, artificial insemination, fixed taxes, energy, and miscellaneous 
expenses. Such expenses, increasing productivity per matrix, will not be increased.

The family income in the higher productivity cluster, showed average, SD, median, IR, minimum and maximum value of $\mathrm{R} \$ 3,002.24 ; \mathrm{R} \$ 1,807.33$; $\mathrm{R} \$ 2,179.50 ; \mathrm{R} \$ 3,238.50 ; \mathrm{R} \$ 1,050.00$ and $\mathrm{R} \$$ $6,750.00$, while the lower productivity cluster showed R\$ 1,511.82; R \$ 1,115.26; R \$ 1,101.75; R\$ 1,248.00; R \$ 240.00; and R \$ 5,796.00, respectively.

One of the main problems was related to the drying of cows in 21 (95.45\%) and 75 (96.15\%) properties in the higher and lower productivity clusters, respectively (Table 1). Animals mostly dried on their own due to the low persistence of lactation and well before the ideal 305 days (LOPES et al., 1996; JUNQUEIRA et al., 1997). Cobuci et al. (2004) reported that this occurs due to genetic and nutritional patterns, since the improvement of lactation persistence in dairy cows is due to genetic engineering and good nutrition. Regarding nutrition, Bovera et al. (2004), Zenou and Miron (2005) and Cannas et al. (2013) reported that, when related to lactation, foods containing less nonfibrous carbohydrates favor the acetate production in the rumen, benefiting milk production and milk fat, as well as the persistence of lactation.

Table 1. Characterization of aspects related to milk production quality of the 100 studied properties, in the Acre Valley mesoregion from March to June 2016 as a function of productivity.

\begin{tabular}{|c|c|c|c|c|c|}
\hline \multirow[t]{2}{*}{ Issue } & \multirow[t]{2}{*}{ Verification } & \multicolumn{2}{|c|}{$\begin{array}{l}\text { Higher productivity } \\
\qquad(\mathrm{n}=22)\end{array}$} & \multicolumn{2}{|c|}{$\begin{array}{l}\text { Lower productivity } \\
\qquad(\mathrm{n}=78)\end{array}$} \\
\hline & & $\mathrm{n}$ & $\%$ & $\mathrm{n}$ & $\%$ \\
\hline \multirow{2}{*}{ Drying of cows } & Alone due to low production & 21 & 95.45 & 75 & 96.15 \\
\hline & By time of lactation & 1 & 4.55 & 3 & 3.85 \\
\hline \multirow{3}{*}{ Yard waiting } & Open sky without floor & 10 & 45.45 & 27 & 34.62 \\
\hline & Covered without floor & 5 & 22.73 & 33 & 42.31 \\
\hline & Open sky with floor & 0 & 0.00 & 0 & 0.00 \\
\hline \multirow{3}{*}{ Milking type } & Covered with floor & 7 & 31.82 & 18 & 23.08 \\
\hline & Manual & 12 & 54.55 & 68 & 87.18 \\
\hline & Mechanical & 10 & 45.45 & 10 & 12.82 \\
\hline \multirow{2}{*}{$\begin{array}{l}\text { Are the ceilings cleaned before } \\
\text { milking? }\end{array}$} & Yes & 15 & 68.18 & 68 & 87.18 \\
\hline & No & 7 & 31.82 & 10 & 12.82 \\
\hline \multirow{2}{*}{$\begin{array}{l}\text { Is the black background mug } \\
\text { test performed? }\end{array}$} & Yes & 18 & 81.81 & 42 & 54.84 \\
\hline & No & 4 & 18.18 & 36 & 46.16 \\
\hline \multirow[t]{2}{*}{ Is the pre-dipping performed? } & Yes & 15 & 68.18 & 32 & 41.03 \\
\hline & No & 7 & 31.82 & 46 & 58.97 \\
\hline \multirow{2}{*}{ Is the post-dipping performed? } & Yes & 0 & 0.00 & 0 & 0.00 \\
\hline & No & 22 & 100.00 & 78 & 100.00 \\
\hline \multirow{2}{*}{ Is the CMT performed? } & Yes & 6 & 27.27 & 17 & 21.79 \\
\hline & No & 16 & 72.73 & 61 & 78.21 \\
\hline \multirow{2}{*}{ Does it have cooling tanks? } & Yes & 4 & 18.18 & 1 & 1.28 \\
\hline & No & 18 & 81.82 & 77 & 98.72 \\
\hline \multirow{2}{*}{ Destination of produced milk } & Sale in natura for dairy products & 17 & 77.27 & 70 & 89.74 \\
\hline & Bulk sale & 5 & 22.73 & 8 & 10.26 \\
\hline
\end{tabular}


In relation to the yard waiting, in $10(45.45 \%)$ and $27(34.62 \%)$ properties they were without cover and floor in the higher and lower productivity clusters, respectively (Table 1). Facilities' design is among the strategic problems related to animal production. In some cases, this item may be responsible for the failure of production system (SILVA et al., 2002). In a country with a tropical climate, such as Brazil, zootechnical constructions, including yard waiting, can aid in comfort and minimize stress in premilking of dairy cattle (BUCKLIN et al., 1991), improving productivity.

Another difference was observed in the milking system, when $10(45.45 \%)$ and $10(12.82 \%)$ had milking machine in the higher and lower productivity clusters, respectively (Table 1). This suggests that producers in the higher productivity cluster were more open for technology adoption. In addition, these producers had higher education levels and could contribute to the producer's perception of the need to adopt technologies. However, these results are very different from those of Marques and Costa (2017) when reported that all properties (100\%) had a milking machine, in a study conducted in the Monte Carmelo-MG region. The tendency of the milk production scenario demands a high quality of qualified workforce, which is scarce and with high costs mainly due to rural exodus (MACULAN, LOPES, 2016). Therefore, the use of equipment that minimizes the human workforce has been advocated by Hansen (2015). Wink and Thaler Neto (2012) reported that when there is a satisfactory average in milk production, producers can invest in the improvement of milking equipment.

The hygiene of ceilings before milking was performed by $15(68.18 \%)$ and $68(87.18 \%)$ of properties. It was observed that $18(81.81 \%)$ and $42(54.84 \%)$ of producers performed the black background mug test in the higher and lower productivity clusters, respectively (Table 1 ). This test, according to Santos and Fonseca (2007), is important to identify animals with clinical mastitis.
The diagnosis of clinical mastitis can be made through symptomatology, such as udder inflammation, milk secretion with lumps, blood, pus, among other pathological secretions (BOUCHOT et al., 1985). However, the subclinical form has a greater epidemiological importance, since it can silently spread in the herd without macroscopic changes in udder inspection or its secretion (BLOOD; RADOSTITIS, 1991). In order to diagnose it, it is necessary to use complementary tests based on the cellular content of milk (BOUCHOT et al., 1985). Thus, the California mastitis test (CMT) is a screening test aimed to detect subclinical mastitis easy to perform and indicated to monitor herds at pasture (FAGLIARI et al., 1983). The prevention of mastitis is fundamental due to its high economic impact, estimated by Demeu et al. (2016) in US\$ 493.03; US\$ 813.78, and US\$ $1,134.53$ for productivities per lactating cow of $10 ; 20$, and $30 \mathrm{~L} /$ day, respectively.

The use of pre-dipping is still less than necessary, being used by only $15(68.18 \%)$ and 32 (41.03\%) producers from the higher and lower productivity clusters, respectively (Table 1). Disinfection is one of the most important aspects of disease prevention for dairy farming (BODDIE et al., 1997). Santana et al. (2001) related poor milk quality to factors as high rates of mastitis, inadequate maintenance and disinfection of equipment, inefficient or inexistent refrigeration, and disqualified workforce, among others.

The non-realization of post-dipping in any property (Table 1) is due to the natural suckling system adopted when, after milking, the calves are kept with the mothers to suckle, being separated hours later. However, hygienic milking is important for preserving milk quality and reducing the risk of disease transmission. Post-dipping is fundamental to prevent contamination by microorganisms acquired during the milking process (SÁ et al., 2011). Expenses with preventive treatment of mastitis represented 5.2\%, according to Lopes et al. 
(2012), while dressing was $26.1 \%$ of the economic impact, which shows an advantage of investing in prevention practice. Demeu et al. (2015) reported similar values $(7.96 \%, 30.13 \%)$ for preventive and dressing treatments, respectively.

The use of milk cooling tanks in the studied properties is rare, being present only in four (18.18\%) and one (1.28\%) properties in the higher and lower productivity clusters, respectively (Table 1). It is important to highlight that the best quality milk shows higher concentration of total solids and protein and lower total concentration of bacteria (DEITOS et al., 2010). Moreover, high thermal stability of milk is important for the dairy industry. The product should reach a temperature of $4{ }^{\circ} \mathrm{C}$ or less in the maximum time of $3 \mathrm{~h}$ after finishing the milking because the higher the ambient temperature, the faster the biochemical changes of the milk that favor bacterial growth will occur (ALBERTON et al., 2012). The adequate storage temperature of the raw milk is fundamental for the quality of raw material and its derivatives (LIMA et al., 2016).

According to Brito (1999), the coliform population can double every $20 \mathrm{~min}$ in the milk kept under average temperature of $30^{\circ} \mathrm{C}$.

The great majority of farmers [17 (77.27\%) and $70(89.74 \%)]$ sold raw milk for dairy products in the higher and lower productivity clusters, respectively (Table 1). However, there is still a common practice in the interiors and countryside of the State of Acre, which is the informal sale of milk (in bulk) transported on motorcycles, bicycles and even horses, stored in disposable bottles without refrigeration, and hygienic and sanitary control.

Regarding the herd health, only two $(9.09 \%)$ and eight $(10.26 \%)$ properties from the higher and lower productivity clusters, respectively, had a health calendar (Table 2); quantities similar to those of Lima et al. (2009) in Quixeramobim-CE.

The single vaccine applied by all owners (100\%) was foot-and-mouth disease, which is mandatory by law, as well as brucellosis, which was not practiced in all properties (Table 2). Nero et al. (2009) found that all producers vaccinated against foot-andmouth disease, while 19 (31.7\%) vaccinated against symptomatic carbuncle, and only seven $(11.7 \%)$ against rabies.

Most of the properties, $(16 ; 72.73 \%$ and 51 ; $65.38 \%$ ), in the higher and lower productivity clusters, respectively, obtained average degree of infestation against ticks (Table 2). Effective control in tick infestation requires the correct use of medicines with animal and pasture management (ARTMANN et al., 2014). Controlling only the tick that parasitizes the animal generates a momentary solution for only $5 \%$ of the parasite population because the remaining $95 \%$ are in free form on pasture (EMBRAPA, 2006).

Concerning the incidence of horn fly (Haematobia irritans), 11 (50.00\%) and $52(66.67 \%)$ herds in the higher and lower productivity clusters, respectively, showed an average degree of infestation (Table $2)$. The damages attributed to this parasite for the Brazilian herd were estimated by Grisi et al. (2014) in US\$ 2.56 billion per year. The losses are related to the transmission of pathogens (anthrax, leucosis, anaplasmosis, and helminth Stephanofilaria $s p$ ). Besides this transmission, the parasite causes stress to the animal (JORGE et al., 2016), contributing to high energy expenditure, reduction in grazing time and water intake, thus delaying weight gain and/ or milk production, decreasing the productivity (BIANCHIN; ALVES, 2002). 
Table 2. Characterization of some aspects related to healthy of herds in the 100 studied properties, in the Acre Valley mesoregion from March to June of 2016 as a function of milk productivity.

\begin{tabular}{|c|c|c|c|c|c|}
\hline \multirow[t]{2}{*}{ Issue } & \multirow[t]{2}{*}{ Verification } & \multicolumn{2}{|c|}{$\begin{array}{l}\text { Higher productivity } \\
(\mathrm{n}=22)\end{array}$} & \multicolumn{2}{|c|}{$\begin{array}{l}\text { Lower productivity } \\
(\mathrm{n}=78)\end{array}$} \\
\hline & & $\mathrm{n}$ & $\%$ & $\mathrm{n}$ & $\%$ \\
\hline \multirow{2}{*}{ Is there a sanitary calendar? } & Yes & 2 & 9.09 & 8 & 10.26 \\
\hline & No & 20 & 90.91 & 70 & 89.74 \\
\hline \multirow{7}{*}{ Vaccines regularly applied } & Foot-and-mouth disease & 22 & 100.00 & 78 & 100.00 \\
\hline & Brucellosis & 20 & 90.91 & 74 & 94.87 \\
\hline & Rabies & 14 & 63.64 & 39 & 50.00 \\
\hline & Clostridial diseases & 16 & 72.73 & 32 & 41.03 \\
\hline & $\mathrm{IBR} / \mathrm{BVD}$ & 0 & 0.00 & 0 & 0.00 \\
\hline & Paratyphoid & 0 & 0.00 & 0 & 0.00 \\
\hline & Leptospirosis & 1 & 4.55 & 0 & 0.00 \\
\hline \multirow{4}{*}{ Infestation of ticks in the herd } & High & 5 & 22.73 & 22 & 28.21 \\
\hline & Average & 16 & 72.73 & 51 & 65.38 \\
\hline & Low & 1 & 4.55 & 5 & 6.41 \\
\hline & High & 10 & 45.45 & 24 & 30.77 \\
\hline \multirow[t]{2}{*}{ Infestation of horn fly in the herd } & Average & 11 & 50.00 & 52 & 66.67 \\
\hline & Low & 1 & 4.55 & 2 & 2.56 \\
\hline \multirow{3}{*}{$\begin{array}{c}\text { Infestation of cattle grub in the } \\
\text { herd }\end{array}$} & High & 0 & 0.00 & 0 & 0.00 \\
\hline & Average & 0 & 0.00 & 0 & 0.00 \\
\hline & Low & 22 & 100.00 & 78 & 100.00 \\
\hline \multirow{2}{*}{$\begin{array}{l}\text { Is worm treatment performed on } \\
\text { the entire bovine population? }\end{array}$} & Yes & 22 & 100.00 & 77 & 98.72 \\
\hline & No & 0 & 0.00 & 1 & 1.28 \\
\hline \multirow{2}{*}{ Is there maternity? } & Yes & 17 & 77.27 & 67 & 85.90 \\
\hline & No & 5 & 22.73 & 11 & 14.10 \\
\hline \multirow{4}{*}{$\begin{array}{l}\text { Diseases that most occur in } \\
\text { calves }\end{array}$} & Diarrhea & 3 & 13.64 & 11 & 14.10 \\
\hline & Pneumonia & 1 & 4.55 & 6 & 7.69 \\
\hline & Tick-borne disease & 4 & 18.18 & 14 & 17.95 \\
\hline & Omphalophlebitis & 0 & 0.00 & 2 & 2.56 \\
\hline \multirow{2}{*}{$\begin{array}{c}\text { Are sick heifers separated from } \\
\text { healthy animals? }\end{array}$} & Yes & 6 & 27.27 & 23 & 29.49 \\
\hline & No & 16 & 72.73 & 55 & 70.51 \\
\hline \multirow{2}{*}{ Does it perform the navel cut? } & Yes & 22 & 100.00 & 78 & 100.00 \\
\hline & No & 0 & 0.00 & 0 & 0.00 \\
\hline
\end{tabular}

The incidence of human botfly (Dermatobia hominis) in the Acre Valley mesoregion is minimal, so that all properties (100\%) showed low infestation (Table 2). The parasitism can cause losses to the herds, which include reduced meat and milk production, delayed animal growth, and intense hide's devaluation (OLIVEIRA-SEQUEIRA et al., 2014)

Regarding worm treatment, all cowmen $(100 \%)$ performed treatment in the entire bovine population (Table 2). In Brazil, despite the lack of official estimates, it is believed that losses due to 
endoparasites are high. Moreover, among all clusters of marketed veterinary medicines, vermifuges rank first in quantity and value of production (AZEVEDO et al., 2008). Girão et al. (1999) recommended worm treatment throughout the herd, however, for growing animals, five applications per year; and for adult animals, including lactating cows, two applications per year.

Regarding maternity, $17(77.27 \%)$ and 67 $(85.90 \%)$ had the higher and lower productivity clusters, respectively (Table 2). It is noteworthy that its absence can become a threat, since the main purpose is the frequent observations of females, allowing the birth monitoring, if there is need for intervention, ensuring that the calf is born in a timely basis and in a satisfactory environment (COELHO et al., 2009).

Tick-borne disease (TBD) was the most frequent disease in the properties: four (18.18\%) and 14 $(17.95 \%)$ in the higher and lower productivity clusters, respectively (Table 2). TBD comprises two well-known diseases: bovine babesiosis, caused by Babesia bovis and B. bigemina protozoa, and anaplasmosis, by rickettsia Anaplasma marginale and A. centrale. Both show high morbidity and high mortality, which occurs mainly in areas of enzootic instability. Almeida et al. (2006) reported that the TBD percentage in herds reaches $11.77 \%$ in the state of Rio Grande do Sul, Brazil.

Diseased heifers were not separated from healthy ones in $16(72.73 \%)$ and $55(70.51 \%)$ properties in the higher and lower productivity clusters, respectively (Table 2). The non-separation entails a serious problem, which is the contamination of other animals. According to Gonçalves (2009), considering all the categories of a milk production system, the highest rates of morbidity and mortality are observed in the cluster of heifers up to weaning. The establishment of early and accurate diagnoses of diseases that affect heifers is undeniably an important factor to indicate effective treatments, minimizing the producer losses (CANNAS et al.,
2006). Furthermore, the authors also emphasized that the incidence of most heifers' health problems, which is the most susceptible animal category, can be maintained at economically acceptable levels if the farmer implants and maintains welldesigned preventive health programs that combine standardized and specific operational procedures, covering all aspects of calf husbandry.

All the properties (100\%) performed navel cut in calves (Table 2). Lima et al. (2017) reported much lower results in the state of Rio Grande do Norte, with only $26.6 \%$. This management is a mandatory practice in calf husbandry, being performed through medicines with disinfectant, healing and repellent action (PEREIRA, 2004), avoiding omphalophlebitis cases.

\section{Conclusions}

Properties from the higher productivity cluster had higher family income, showed a larger number of covered and floored yard waiting, and cows with better body conditions at calving. Furthermore, they showed higher pre-dipping rates and used more technologies, such as expansion tank and milking machine. Moreover, they obtained higher rates of vaccination against clostridial disease and rabies.

The productive factors found in the researched properties show the need for improved management so that they can obtain better results and hence better profitability.

Statistical significance was observed between the higher and lower productivity clusters for productivity (L/ha/year) and family income ( $\mathrm{R} \$ /$ month) among the categories from independent quantitative variables collected through a questionnaire.

\section{References}

ALBERTON, J.; ALBERTON, L. R.; PACHALY, J. R.; OTUTUMI, L. K.; ZAMPIERI, T. M.; AGOSTINIS, R. O. Estudo da qualidade do leite de amostras obtidas 
de tanques de resfriamento em três regiões do estado do Paraná. Arquivo de Ciência Veterinária e Zoologia, Umuarama, v. 15, n. 1, p. 5-12, 2012.

ALMEIDA, M. B.; TORTELLI, F. P.; RIET-CORREA, B.; FERREIRA, J. L. M.; SOARES, M. P.; FARIAS N. A. R.; RIET-CORREA, F.; SCHILD, A. L. Tristeza parasitária bovina na região sul do Rio Grande do Sul: estudo retrospectivo de 1978-2005. Pesquisa Veterinária Brasileira, Seropédica, v. 26, n. 2, p. 237-242, 2006.

ANDRADE, C. M. S.; SÁ, C. P.; VALENTIN, J.; CAVAlCANTE, F. A. Sistema de produção de leite a pasto no Acre. Rio Branco: Empresa Brasileira de Pesquisa Agropecuária, EMBRAPA Acre, 2014. 54 p. (Comunicado técnico, 6).

ARTMANN, T. A.; TOMA, H. S.; PINHEIRO, J. N.; ROMERO, J.; CARVALHO, A. M.; MONTEIRO TOMA, C. D. Eficiência produtiva brasileira e sua associação ao melhoramento genético animal. Revista Cientifica de Medicina Veterinária, Garça, v. 22, n. 4, p. 77-89, 2014.

AZEVEDO, D. M. M. R.; ALVES, A. A.; SALES, R. O. Principais ecto e endoparasitas que acometem bovinos leiteiros no Brasil: uma revisão. Revista Brasileira de Higiene e Sanidade Animal, Fortaleza, v. 2, n. 1, p. 43$55,2008$.

BARBETTA, P. A. Estatística aplicada às ciências sociais. 7. ed. Florianópolis: Editora da UFSC, 2003. 118 p.

BIANCHIN, I.; ALVES, R. G. Mosca-dos-chifres, Haematobia irritans: comportamento e danos em vacas e bezerros Nelore antes da desmama. Pesquisa Veterinária Brasileira, Seropédica, v. 22, n. 2, p. 109-113, 2002.

BLOOD, D. C.; RADOSTITIS, O. M. Clínica veterinária. 7. ed. Rio de Janeiro: Guanabara Koogan, 1991. 463 p.

BODDIE, R. L.; NICKERSON, S. C.; ADKINSON, R. W. Efficacies of teat germicides containing $0.5 \%$ chlorhexidine and $1 \%$ iodine during experimental challenge with Staphylococcus aureus and Streptococcus agalactiae. Journal Dairy Science, Champaign, v. 80, n. 11, p. 2809-2814, 1997.

BOUCHOT, M. C.; CATEL, J.; CHIROL, C.; GANIERE, J. P.; MENEC, L. E. M. Diagnostic bactériologique des infections mammaries des bovins. Recuell de Médicine. Veterinarie, Paris, v. 161, n. 7, p. 57-577, 1985.

BOVERA, F.; CUTRIGNELLI, M. I.; CALABRÒ, S.; PICCOLO, G.; TUDISCO, R.; ZICARELLI, F.; PICCOLO, V.; INFASCELLI, F. Effect of nonstructural carbohydrate dietary content on the productive performance of Sarda primiparous ewes. Italian Journal of Animal Science, Pisa, v. 3, n. 1, p. 61-70, 2004.
BRASIL. Ministério da Agricultura, Pecuária e Abastecimento. Instrução Normativa $n^{\circ}$ 62, de 29 de dezembro de 2011. Dispõe sobre regulamentos técnicos de produção, identidade, qualidade, coleta e transporte de leite. Diário Oficial [da] União, Brasília, DF, 30 dez. 2011. Seção 1, p. 6-11.

BRITO, M. A. V. P. Conceitos básicos de qualidade, sanidade do gado leiteiro. Juiz de Fora: EMBRAPA Gado de Leite, 1999. 32 p.

BUCKLIN, R. A.; BEEDE, D. K.; BRAY, D. R. Methods to relieve heat stress for dairy cows in hot, humid climates. Applied Engineer Agricultural, Delhi, v. 7, n. 2, p. 241-252, 1991.

CANNAS, A.; NUDDA, A.; PULINA, G. Decreasing dietary NFC concentration during mid-lactation of dairy ewes: does it result in higher milk production? Small Ruminant Research, Philadelphia, v. 111, n. 1-3, p. 4149, 2013.

CANNAS, J. S.; NOORDHUIZEN, J. P. T. M.; VAGNEUR, M.; BEXIGA, R.; GELFERT, C. C.; BAUMGARTNER, W. The future of veterinarians in bovine herd health management. The bovine practitioners in Europe: perspectives and constraints. In: WORLD BUIATRICS CONGRESS, 2006, Nice. Proceedings... Nice: [s.n.], 2006. p. 44-56.

COBUCI, J. A.; EUClydES, R. F.; COSTA, C. N.; LOPES, P. S.; TORRES, R. A.; PEREIRA, C. S. Análises da persistência na lactação de vacas da Raça Holandesa, usando produção no dia do controle e modelo de regressão aleatória. Revista Brasileira de Zootecnia, Viçosa, MG, v. 33, n. 3, p. 546-554, 2004.

COElHO, S. G.; GONÇAlVES, L. C.; COSTA, T. C.; FERREIRA, C. S. Alimentação de bezerras. In: GONÇALVES, L. C.; BORGES, I.; FERREIRA, P. D. S. Alimentação de gado leiteiro. 3. ed. Belo Horizonte: FEPMVZ, 2009. p. 50-98.

CORRAR, L. J.; PAULO, E.; DIAS FILHO, J. M. Análise multivariada: para os cursos de Administração, Ciências Contábeis e Economia. São Paulo: Atlas. 2009. 144 p.

DEITOS, A. C.; MAGGIONI, D.; ROMERO, E. A. Produção e qualidade de leite de vacas de diferentes grupos genéticos. Campo Digit@l, Campo Mourão, v. 5, n. 1, p. 26-33, 2010.

DEMEU, F. A.; LOPES, M. A.; COSTA, G. M.; ROCHA, C. M. B. M.; SANTOS, G. Efeito da produtividade diária de leite no impacto econômico da mastite em rebanhos bovinos. Boletim da Indústria Animal, Nova Odessa, v. 73, n. 1, p. 53-61, 2016.

DEMEU, F. A.; LOPES, M. A.; COSTA, G. M.; ROCHA, C. M. B. M.; SANTOS, G.; FRANCO NETO, A. 
Influência da escala de produção no impacto econômico da mastite em rebanhos bovinos leiteiros. Revista Ceres, Viçosa, MG, v. 62, n. 3, p. 167-174, 2015.

EMPRESA BRASILEIRA DE PESQUISA AGROPECUÁRIA - EMBRAPA. Criação de bovinos de corte no Estado do Pará - manejo sanitário. Belém: Embrapa Amazônia Oriental, 2006. 47 p. (Comunicado técnico).

FAGLIARI, J. J.; RIBEIRO, A, M.; GONÇALVES, T. A. Mastite bovina: comparação entre os resultados obtidos pelo California Mastitis Test e o exame bacteriológico. Arquivo Brasileiro de Medicina Veterinária e Zootecnia, Belo Horizonte, v. 35, n. 3, p. 310-315, 1983.

FERRAZZA, R. A.; LOPES, M. A.; MORAES, F. M.; BRUHN, F. R. P. Índices de desempenho zootécnico e econômico de sistemas de produção de leite com diferentes níveis tecnológicos. Semina: Ciências Agrárias, Londrina, v. 36, n. 1, p. 485-496, 2015.

GIRÃO, E. S.; LEAL, J. A.; GIRÃO, R. N. Verminose bovina. Teresina: EMBRAPA Meio-Norte, 1999. 30 p. (Comunicado Técnico).

GONÇALVES, R. C. O sistema respiratório na sanidade de bezerros. Ciência Animal Brasileira, Goiânia, v. 1, n. 1, p. 173-189, 2009.

GRISI, L.; LEITE, C. R.; MARTINS, S. R. J.; BARROS, M. T. A.; ANDREOTTI, R.; CANÇADO, D. H. P.; LEÓN, P. A. A.; PEREIRA, B. J.; VILLELA, S. H. Reassessment of the potential economic impact of cattle parasites in Brazil. Revista Brasileira de Parasitologia Veterinária, Jaboticabal, v. 23, n. 2, p. 150-156, 2014.

GUDKOVA, S.; CHEREPANOVA, N.; DUPLYAKOV, D.; GOLOVINA, G.; KHOKHLUNOV, S.; SURKOVA, E.; ROTAR, O.; KONRADI, A.; SHLYAKHTO, E. Lifetime prevalence of transient loss of consciousness in an Urban Russian population. Arquivo Brasileiro de Cardiologia, Rio de Janeiro, v. 106, n. 5, p. 382-388, 2016.

HAIR, F. J.; BLACK, W. C.; BABIN, B. J.; ANDERSON, R. E.; TATHAM, R. L. Análise multivariada de dados. 6. ed. Porto Alegre: Bookman. 2009. 122 p.

HANSEN, B. G. Robotic milking-farmer experiences and adoption rate in Jæren, Norway. Journal of Rural Studies, Wales, v. 41, n. 5, p. 109-117, 2015.

IBM Corp. Released. IBM SPSS Statistics for Windows. Version 20.0. Armonk: IBM Corp., 2011.

JORGE, M. A.; ROSA, C.; SANTOS, G. Impacto econômico da mosca dos chifres em bovinos de corte. Revista iPecege, Piracicaba, v. 2, n. 3, p. 27-39, 2016.
JUNQUEIRA, L. V.; NEIVA, R. S.; VEIGA, R. D.; TEIXEIRA, N. M.; DURÃES, M. C.; LOPES, M. A. Estudo das curvas de lactação de vacas holandesas de alguns rebanhos do estado de Minas Gerais, por intermédio de uma função gama incompleta. Revista Brasileira de Zootecnia, Viçosa, MG, v. 26, n. 1, p. 11091118, 1997.

KAUFMAN, L.; ROUSSEAU, W. Finding groups in data: an introduction to cluster analysis. $2^{\text {th }}$ ed. New York: John Wiley \& Son, 1990. 111 p.

LIMA, A. F.; BESSA, E. N.; FIRMINO, S. S.; PAIVA, K. A. R.; ANDRE, W. P. P. Caracterização da bovinocultura leiteira do município de Taboleiro Grande, Rio Grande do Norte. ACSA - Agropecuária Científica do SemiÁrido, Campina Grande, v. 13, n. 1, p. 29-34, 2017.

LIMA, L. N. C.; TÔRRES, L. S.; SILVA, L. K. B.; SANTOS, R. S.; CRUZ, T. M. S.; FIGUEIREDO, E. L. Avaliação microbiológica do leite in natura e pasteurizado comercializado no município de Benevides-PA. Scientia Plena, Aracaju, v. 12, n. 6, p. 1-6, 2016.

LIMA, P. O.; DUARTE, L. S.; SOUZA, A. Z. B.; AQUINO, T. M. F.; OLIVEIRA, C. S. Perfil dos produtores rurais do município de Quixeramobim no estado do Ceará. Revista Caatinga, Mossoró, v. 22, n. 4, p. 255-259, 2009.

LOPES, M. A.; CARDOSO, M. G.; CARVALHO, F. M.; LIMA, A. L. R.; DIAS, A. S.; CARMO, E. A. Efeito do tipo de sistema de criação nos resultados econômicos de sistemas de produção de leite na região de Lavras (MG) nos anos 2004 e 2005. Ciência Animal Brasileira, Goiânia, v. 8, n. 2, p. 74-92, 2007.

LOPES, M. A.; DEMEU, F. A.; ROCHA, C. M. B. M. da; COSTA, G. M. da; FRANCO NETO, A.; SANTOS, G. Avaliação do impacto econômico da mastite em rebanhos bovinos leiteiros. Arquivos do Instituto Biológico, São Paulo, v. 79, n. 4, p. 477-483, 2012.

LOPES, M. A.; MORAES, F.; CARVALHO, F. M.; PERES, A. A. P.; BRUHN, F. R. P.; REIS, E. M. B. Efeito de índices técnicos e gerenciais na rentabilidade da atividade leiteira com diferentes níveis tecnológicos. Revista Científica de Produção Animal, Areia, v. 17, n. 2, p. 92-102, 2015a.

LOPES, M. A.; MORAES, F.; CARVALHO, F. M.; PERES, A. A. C.; BRUHN, F. R. P.; REIS, E. M. B. Efeito do nível tecnológico na rentabilidade de sistemas de produção de leite participantes do programa Balde Cheio: um estudo multicascos. Semina: Ciências Agrárias, Londrina, v. 36, n. 4, p. 2909-2922, 2015 b.

LOPES, M. A.; NEIVA, R. S.; VALENTE, J.; MARTINEZ, M. L.; VEIGA, R. D.; SILVA, A. R. P. 
da; FREITAS, A. F. de. Aplicação da função tipo gama incompleta no estudo da curva de lactação de vacas da raça Holandesa variedade preto e branca mantidas em sistema intensivo de produção. Revista Brasileira de Zootecnia, Viçosa, MG, v. 25, n. 1, p. 1086-1101, 1996.

LOPES, M. A.; REIS, E. M. B.; FERRAZZA, R. N. Formulário de diagnóstico da propriedade leiteira. Lavras: UFLA, 2016. 19 p.

MACULAN, R.; LOPES, M. A. Ordenha robotizada de vacas leiteiras: uma revisão. Boletim. da Indústria Animal, Nova Odessa, v. 73, n. 1, p. 80-87, 2016.

MAROCO, J. Análise estatística com utilização do SPSS. 3. ed. Lisboa: Sílabo, 2010. 822 p.

MARQUES, D. A.; COSTA, C. Perfil tecnológico de fazendas leiteiras assistidas por uma empresa de consultoria veterinária na região de Monte Carmelo-MG. Revista Getec-Gestão Tecnologia e Ciências, Monte Carmelo, v. 6, n. 13, p. 69-86, 2017.

NERO, L. A.; MATTOS, M. R.; BELOTI, V.; BARROS, M. A. F.; PINTO, J. P.; ANDRADE, N. J.; SILVA, W. P.; FRANCO, B. D. G. Leite cru de quatro regiões leiteiras brasileiras: perspectivas de atendimento dos requisitos microbiológicos. Ciência e Tecnologia dos Alimentos, Campinas, v. 25, n. 1, p. 191-195, 2005.

NERO, L. A.; VIÇOSA, G. N.; PEREIRA, F. V. Qualidade microbiológica do leite determinada por características de produção. Ciência e Tecnologia de Alimentos, Campinas, v. 29, n. 2, p. 386-390, 2009.

NOVO, A. L. M.; SCHIFFLER, E. A. Princípios básicos para produção econômica de leite. São Carlos, São Paulo: EMBRAPA Pecuária Sudeste, 2006. 27 p.

OLIVEIRA-SEQUEIRA, T. R. G.; AMORIM, R. M.; BORGES, A. S.; BRANT, M. P. R. Eficácia terapêutica e residual de seis formulações inseticidas sobre $\mathrm{O}$ parasitismo por larvas de dermatobia hominis em bovinos. Veterinária e Zootecnia, Botucatu, v. 21, n. 1, p. 177-186, 2014.

PEREIRA, A. L. M.; COSTA, A. F.; VESCHI, J. L. A.; ALMEIDA, K. S. Soroprevalência da leucose enzoótica bovina. Revista Científica Eletrônica de Medicina Veterinária, Garça, v. 23, n. 1, p. 47-59, 2014.

PEREIRA, J. C. Criação de bezerros de rebanhos leiteiros para produção de carne. Brasília: SENAR, 2004. 32 p.

REIS, E. M. B.; VIEIRA, J. A.; LOPES, M. A.; DEMEU, F. A.; BRUHN, F. R. P. Identificação de pontos fracos e fortes associados à qualidade do leite em propriedade leiteiras de agricultura familiar. Revista PUBVET, Maringá, v. 11, n. 9, p. 889-900, 2017.
SÁ, O. R.; FRANÇA, N.; ESPER, K. C. P.; PEREIRA, K. P.; SOUZA, N. C.; SILVA, T. M. Avaliação da qualidade higiênico-sanitária do leite cru refrigerado produzido em propriedades leiteiras do município de Passos e região. Ciência et Praxis, Passos, v. 4, n. 8, p. 22-34, 2011.

SANTANA, E. H. W.; BELOTI, V.; BARROS, M. A. F. Contaminação do leite em diferentes pontos do processo de produção: I. Microrganismos aeróbios mesófilos e psicrotróficos. Semina: Ciências Agrárias, Londrina, v. 22, n. 2, p. 145-154, 2001

SANTOS, M. V.; FONSECA, L. F. L. Estratégias para controle de mastite e melhoria da qualidade do leite. Barueri: Manole, 2007. 314 p.

SILVA, G. S. L.; SILVA, J. B. A importância da definição de um modelo de negócio na pecuária leiteira para a escolha da estratégia de comercialização. Revista de Administração do Sul do Pará, Redenção, v. 3, n. 1, p. 49-66, 2016.

SILVA, I. J. O.; PANDORFI, H.; ACARARO JUNIOR, I.; PIEDADE, S.; MOURA, D. Efeitos da climatização do curral de espera na produção de leite de Vacas Holandesas. Revista Brasileira de Zootecnia, Viçosa, MG, v. 31, n. 5, p. 2036-2042, 2002.

WILlERS, C. D.; FERRAZ, S. P.; CARVALHO, L. $\mathrm{S}$. Determination of indirect water consumption and suggestions for cleaner production initiatives for the milk-producing sector in a Brazilian middle-sized dairy farming. Journal of Cleaner Production, Brno, v. 72, n. 1, p. 146-152, 2014

WINK, C. A.; THALER NETO, A. Perfil de propriedades leiteiras de Santa Catarina em relação à Instrução Normativa 51. Revista Brasileira de Saúde e Produção Animal, Salvador, v. 13, n. 2, p. 296-305, 2012.

ZENOU, A.; MIRON, J. Milking performance of dairy ewes fed pellets containing soy hulls as starchy grain substitute. Small Ruminant Research, Philadelphia, v. 57, n. 2-3, p. 187-192, 2005.

ZOCCAL, R.; CARNEIRO, A. V.; JUNQUEIRA, R.; ZAMARCO, M. A. A nova pecuária leiteira brasileira. In: BARBOSA, S. B. P.; BATISTA, A. M. V.; MONARDES, H. In: CONGRESSO BRASILEIRO DE QUALIDADE DO LEITE, 3., 2008, Recife. Anais... Recife: CCS Gráfica e Editora, 2008. v. 1, p. 85-95. 
